\title{
CHEMICAL ENGINEERING IN THE IMPERIAL COLLEGE OF SCIENCE, LONDON
}

\begin{abstract}
HE endowment of the Courtauld chair of chemical engineering in the Imperial College of Science and Technology (University of London) in 1945 was a generous recognition by industry of the pioneering efforts of the Collogo in establishing chemical engineering as a distinctive academic discipline. The first holder of the chair, Prof. D. M. Newitt, has recently retired having reached the age limit. Prof. Newitt had a long association with the College. After a period of training in the chemical industry, he graduated in chemistry at the Royal College of Science in 1921 and later studied under J. W. Hinchley in the Department of Chemical Technology.

Under Newitt's leadership the teaching of chemical engineering in the College developed rapidly in the post-war years ; his constant purpos was to rationalize this teaching by emphasizing its fundamental relationship with the physical sciences. Of his former students and colleagues some twelve now hold chairs in other universities in Great Britain and overseas and many are now leaders in various branches of industry. He was a founder member of the Institution of Chemical Engineers and was its president in 1949 and 1950.
\end{abstract}

A second chair of chemical engineering science was instituted in the College in 1957 and has been held in turn by P. Danckwerts and K. G. Denbigh.

Since its inception under Bone and Hinchley in 1912, the Department of Chemical Engineering and Chemical Technology has been noted for strong and active research groups in various branches of pure and applied physics, chemistry and chemical engineering. Prof. Newitt has given continued support to this tradition by his insistence on the value of original work as an essential and not meraly an optional component in the education and training of technologists, and by his leadership in the field of research at high pressures. Newitt was elected a fellow of the Royal Society in 1942; an honorary doctorate was conferred on him by the University of Toulouse in 1961. He will continue to be a valued member of the Department as Senior Research Fellow of Imperial College and as emeritus professor in the University of London.

The new holder of the Courtauld chair, Prof. K. G. Denbigh, is already well known to the College and University for his work since 1959 as professor of chemical engineering science in the Department. He graduated in the University of Leeds in 1932 and received the $\mathrm{Ph} . \mathrm{D}$. degree in 1934. After four years service with Imperial Chemical Industries at Billing. ham he was lecturer in chemistry in the University of Southampton during 1938-41. During the War years from 1941 until 1945 he was chief chemist at the Royal Ordnance Factory, Bridgwater, and he returned to Imperial Chemical Industries in 1945 as head of the Physical Chemistry Department of the Akers Laboratory at Welwyn. He went to the University of Cambridge in 1948 as lecturer in chemical engineering and in 1955 became professor of chemical technology in the University of Edinburgh.

Prof. Denbigh's varied experience of industrial and university activities in chemical engineering and chemical technology shculd prove of continued value and fruitfulness in his new post as Courtauld professor.
A. R. UbBelohde

\section{THE UNIVERSITY OF LIVERPOOL: THE NEW BUILDING IN THE FACULTY OF VETERINARY SCIENCE}

T

HE Faculty of Veterinary Science in the University of Liverpool had an open day for its new building on October 27 and 28. This building (Fig. 1), which houses the Departments of Veterinary Anatomy and Veterinary Pathology and Bacteriology, had been occupied by them at the beginning of the year.

The new building, which is part of the University's development plan, lies on the north side of the science precinct, facing into what will be an open space also bounded by Chemistry, Physics and Mathematics buildings. The Veterinary Building bas an area of 46,130 sq. ft. and cost approximately $£ 250,000$, 90 per cent of which was provided by a grant through the University Grants Committee. The architect is Mr. E. Maxwell Fry. It comprises a main building of three floors, flanked on each side by single-storey wings built around open yards. The ground-floor contains the Faculty offices, staff library and students' reading room, the Department of Veterinary Anatomy staff laboratories, and a photographic unit for the Department of Veterinary Pathology and Bacteriology. The first-floor accommodation is grouped around a central museum, which is shared by both Departments, and extends from one side of the building to the other. Each Department also has its own practical classroom with bench accommodation for forty students.

The sccond floor is occupied by the Department of Veterinary Pathology and Bacteriology. Accom. modation includes staff laboratories, a unit for virological work and service rooms for the washing and sterilization of glassware, preparation of media, tissue processing and a museum workshop. There is also a laboratory for postgraduate practical classes with bench space for sixteen students.

The Anatomy wing includes a large dissecting room with cold store and $\mathrm{X}$-ray facilities for anatomical studies; a tank room and preparation rooms are adjacent. Around the open yard are large animal loose-boxes, accommodation for laboratory animals and experimental rooms. The teaching accommodation comprises a lecture theatre and a tutorial reom.

The Pathology wing also has a large open yard bounded on its southern end by the Veterinary Investigation Centre of the Ministry of Agriculture, Fisheries and Food. Opening into this yard are loose-boxes for farm animals and a unit for the breeding and maintenance of stocks of laboratory 


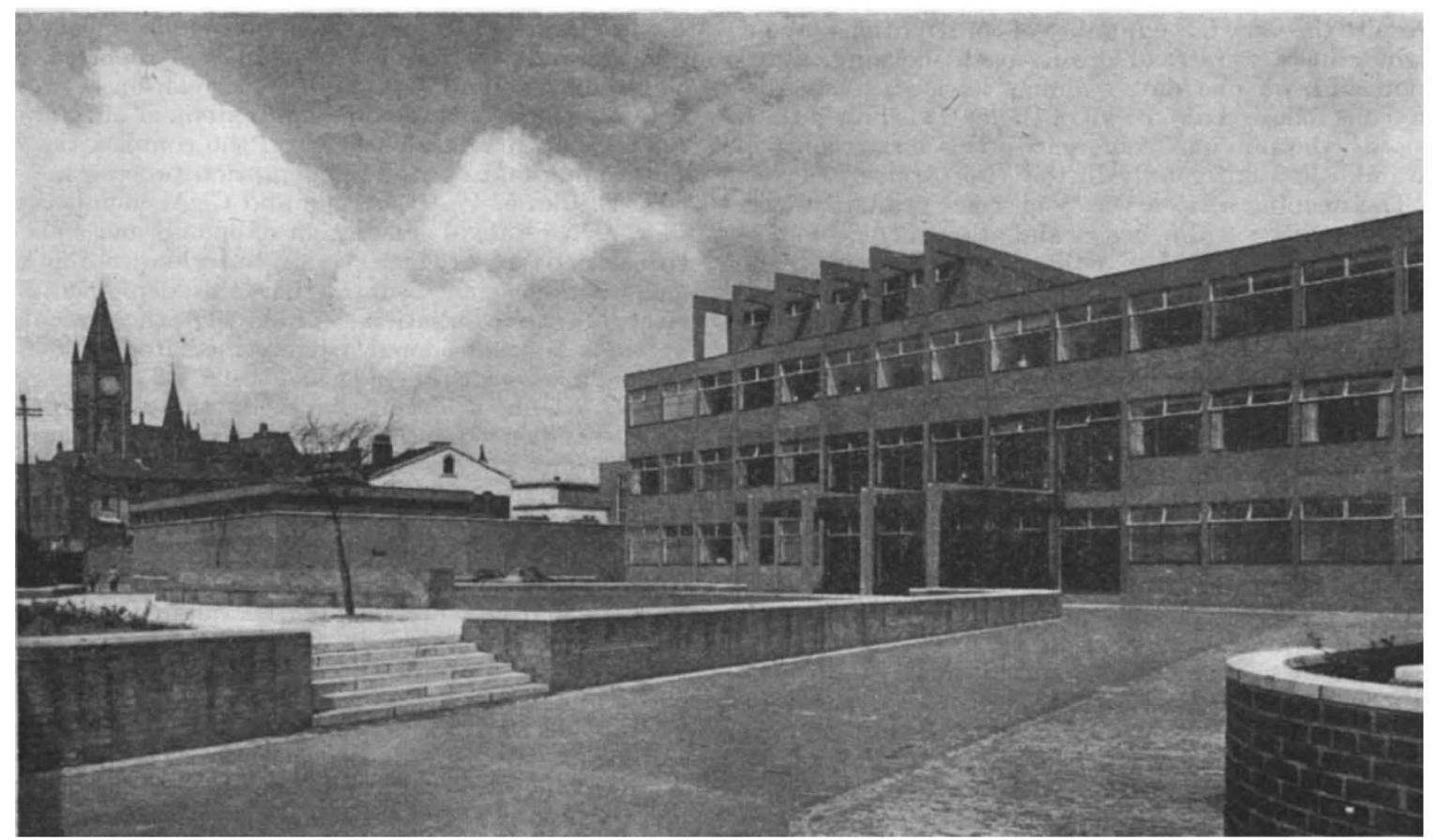

Jig. 1

animals. At the north end of the enclosure are postmortem rooms, a cold store, a gas cremator and a diagnosis laboratory. The wing is completed by a large lecture theatre with seating for more than one hundred people.

The Department of Veterinary Anatomy is responsible for the teaching of gross and topographical anatomy, histology and embryology. Recently installed equipment includes $\mathrm{X}$-ray apparatus suitable for work with farm animals, including ciné radiography with a 9-in. image intensifier. There is also a completely equipped experimental operating theatre. Research projects in hand include studies on growth-rate of tissues, the hormonal control of lactation, the transport and fate of gametes, and structure and function in the hip joint.

The chair of veterinary anatomy has been reestablished and Dr. A. S. King, of the University of Bristol, will be taking up the appointment in January.

The Department of Veterinary Pathology and Bacteriology undertakes the teaching of gross morbid anatomy, histopathology and microbiology including virology. The Department is also responsible for instruction in applied pathology, including the principles of food hygiene with particular reference to food of animal origin. The equipment of the Department now comprises all the more modern apparatus necessary for microbiological and histopathological studies, including a cold laboratory operating at $4^{\circ} \mathrm{C}$. and a unit able to provide all the photographic requirements of the Department.

Research work on the microbiological side of the Department consists of a series of projects designed to elucidate the pathogenesis of enteric infections, using fowl typhoid, coli-bacillosis in calves, and bowel œdema in pigs as models. The role of hypersensitivity in producing the lesions associated with these infections is of particular interest. Another problem in a somewhat similar field are the ante-mortem factors which may govern the post-mortem invasion of the carcass. This problem has a particular relevance to meat hygiene.

Research in histopathology in concerned with demyelination in the central nervous system, especially in swayback in sheep, and the histopathological changes in the reproductive system in certain forms of vitamin A deficiency.

Apart from teaching and research responsibilities, the Department undertakes a considerable volume of routine diagnostic investigations for the clinical Departments of the Veterinary School, and some work for veterinary surgeons in practice. In 1960 this amounted to 663 post-mortem examinations and 1,186 other diagnostic tests.
D. L. Hughes

\section{PIGMENT CELLS IN ANIMALS}

$\mathrm{T}$ HE fifth International Pigment Cell Conference, in a series initiated by the late Myron Gordon, was held in New York during October 11-14 under the auspices of the New York Academy of Sciences and was organized jointly by them and by Dr. Vernon Riley, of the Sloan-Kettering Institute for Cancer Research, Rye, Now York, and Dr. Joseph G. Fortner, of the Memorial Sloan-Kettering Cancer Center, New York. As in previous conferences, contributions ranged from the fields of medical statistics and dermatology to those of genetics and cell chemistry. The generosity of the New York Academy of Sciences and the Damon Runyon Fund for Cancer Research enabled contributors from many lands to attend. 